\title{
Absorpsi Tari Bedhaya Bedhah Madiun Gaya Yogyakarta di Mangkunegaran Masa Pemerintahan Mangkunegara VII
}

\author{
Sriyadi, ${ }^{*}$ R. M. Pramutomo \\ Program Studi Penciptaan dan Pengkajian Seni, Pascasarjana Institut Seni Indonesia Surakarta \\ Jl. Ki Hadjar Dewantara Jebres, Surakarta - Indonesia \\ *Alamat korespondensi: yadisri375@gmail.com \\ DOI: https://doi.org/10.14710/jscl.v5i1.26657
}

Diterima/Received: 21 November 2019; Direvisi/Revised: 26 Maret 2020; Disetujui/Accepted: 7 April 2020

\begin{abstract}
The history of dance in Mangkunegaran is basically using the Surakarta style. During the reign of Mangkunegara VII there was the dance called Bedhaya Bedhah Madiun dance with Yogyakarta style. This study tries to describe the factors of Yogyakarta dance style in Pura Mangkunegaran by choosing a specific dance called Bedhaya Bedhah Madiun. It is ethnochoreological research using the historical approach. The existence of the Bedhaya Bedhah Madiun dance in Pura Mangkunegaran is mostly influenced by the social and political demands of Mangkunegaran. As the top of the social and political hierarchy in Mangkunegaran, Mangkunegara VII' has policy impacts on the budgetary of the Bedhaya Bedhah Madiun dance in Mangkunegaran. The most challenging policy is the political nuance which is carried out with the Yogyakarta Sultanate Palace. Mangkunegara VII's marriage to Gusti Timur was blessed with a daughter, who is confirmed by her ability in dancing bedhaya and srimpi. Around 1934 Gusti Nurul was permitted to be sent to Krida Beksa Wirama to study the Yogyakarta style of bedhaya and srimpi dance. One of the learning materials is the Bedhaya Bedhah Madiun dance, which is then presented at Pura Mangkunegaran.
\end{abstract}

Keywords: History of Dance; Absorption; Bedhaya Bedhah Madiun; Mangkunegaran.

\section{Abstrak}

Tari yang berkembang di Mangkunegaran pada dasarnya menggunakan gaya Surakarta. Pada masa pemerintahan Mangkunegara VII terdapat tari Bedhaya Bedhah Madiun dengan gaya Yogyakarta. Artikel ini bertujuan mendeskripsikan faktor keberadaan tari gaya Yogyakarta di Mangkunegaran, dengan memilih studi kasus pada tari Bedhaya Bedhah Madiun. Pendekatan yang digunakan dalam studi ini adalah etnokoreologi dengan metode penelitian sejarah. Keberadaan tari Bedhaya Bedhah Madiun di Mangkunegaran dipengaruhi oleh beberapa faktor. Keadaan sosial politik yang dihadapi Mangkunegaran sangat memengaruhinya. Sebagai puncak hierarki strata sosial di Mangkunegaran, kebijakan Mangkunegara VII berdampak pada kemunculan tari Bedhaya Bedhah Madiun di Mangkunegaran. Kebijakan yang paling berpengaruh terhadap hal itu adalah pelaksanaan politik pernikahan dengan Kasultanan Yogyakarta. Pernikahan Mangkunegara VII dengan Gusti Timur dikaruniai seorang putri yaitu G.R.Aj. Siti Nurul Kamaril Ngasarati Kusumawardani yang memiliki kemampuan menari bedhaya dan srimpi. Penegasan kedudukan tidak lepas dari peranan Gusti Timur, sebagai ibu dan permaisuri. Sekitar tahun 1934 Gusti Nurul disertai beberapa kerabat disekolahkan ke Kridha Beksa Wirama untuk belajar tari bedhaya dan srimpi gaya Yogyakarta. Salah satu materi pembelajarannya adalah tari Bedhaya Bedhah Madiun, yang kemudian disajikan di Mangkunegaran.

Kata Kunci: Sejarah Tari; Absorpsi; Bedhaya Bedhah Madiun; Mangkunegaran.

\section{Pendahuluan}

Pura Mangkunegaran yang berada di Kota Surakarta dahulu merupakan sebuah pusat pemerintahan kadipaten yang terbentuk pada 1757. Kadipaten Mangkunegaran didirikan oleh R.M. Said atau Pangeran Sambernyawa. R.M. Said adalah putra Pangeran Arya Mangkunegara, yang lahir pada 7 April 1726. Kadipaten Mangkunegaran berdiri berkat perjuangan R.M. Said melawan Belanda, Susuhunan Paku Buwana II, dan Pangeran Mangkubumi (Sultan Hamengku Buwana I). Perlawanan itu berlanjut ketika Surakarta di bawah pemerintahan Susuhunan Paku 
Buwana III. Perlawanan berakhir setelah perjanjian Salatiga yang menetapkan R.M. Said sebagai Adipati dengan gelar K.G.P.A.A. Mangkunegara I (Pakempalan Pengarang Serat ing Mangkunagaran dan Kamajaya, 1993:248-49).

Kadipaten Mangkunegaran adalah salah satu wilayah Kasunanan Surakarta, sehingga dalam sistem pemerintahan berada di bawah kekuasaan Kasunanan yang merupakan kerajaan (Sunarmi, 2005:35). Bentuk gaya tari yang digunakan di Mangkunegaran adalah tari gaya Surakarta, karena kekuasaannya berada di bawah Kasunanan Surakarta. Pada masa pemerintahan K.G.P.A.A. Mangkunegara VII terdapat karya tari yang nama dan bentuk geraknya menyerupai tari gaya Kasultanan Yogyakarta. Karya tari tersebut adalah tari Bedhaya Bedhah Madiun, tari Srimpi Muncar, tari Srimpi Pandhelori, tari Golek Montro, tari Golek Lambangsari, dan tari Golek Clunthang. Pada dasarnya tari gaya Yogyakarta yang berkembang di Mangkunegaran adalah tari putri, sedangkan tari putra menggunakan tari gaya Surakarta (Koentjaraningrat, 1984:297).

Tari Bedhaya Bedhah Madiun di Mangkunegaran adalah salah satu karya tari dengan nama, gendhing, dan bentuk gerak yang menyerupai karya tari di Kasultanan Yogyakarta. Tari Bedhaya Bedhah Madiun berdasar nama gendhing pokok yang digunakan disebut tari Bedhaya Gandakusuma. Tari Bedhaya Bedhah Madiun menceritakan peperangan Panembahan Senapati melawan Retna Dumilah. Panembahan Senapati adalah raja Mataram Islam yang pertama. Kerajaan Mataram Islam pada masa pemerintahan Panembahan Senapati melakukan ekspansi dengan menaklukan beberapa kadipaten, salah satunya adalah Kadipaten Madiun. Kerajaan Mataram memenangkan pertempuran. Rangga Jumena, Adipati Madiun kemudian melarikan diri dan mengutus putrinya, Retna Dumilah untuk melawan Panembahan Senapati. Panembahan Senapati dan Retna Dumilah akhirnya jatuh cinta dan menikah (Sajid, 1985:1-3).

Struktur sajian tari Bedhaya Bedhah Madiun terbagi menjadi tiga, yaitu maju beksan, beksan, dan mundur beksan. Gendhing yang digunakan dalam bagian maju beksan dan mundur beksan adalah gendhing Lagon dan gendhing Ladrang Langenbranta dengan garap irama tanggung. Pada bagian beksan dibagi menjadi dua yaitu beksan pokok I dengan Gendhing Gandakusuma, Gending Gambuh, dan Ladrang Gurisa Mengkreng, serta bagian beksan pokok II dengan Gendhing Ketawang Widharingtyas. Gendhing dalam tari Bedhaya Bedhah Madiun menggunakan Laras Pelog Pathet Nem.

Pola gerak yang digunakan dalam tari Bedhaya Bedhah Madiun di Mangkunegaran menyerupai pola gerak gaya Yogyakarta. Pola gerak tersebut adalah kapang-kapang, sembahan nglayang, nggrudha, nggenceng, gidrah, pendhapan, gudawa, nduduk wuluh, atrap sumping, ulap-ulap, atur-atur, kipat gajahan, lampah sekar, lembehan sirig, tinting, dan sebagainya. Perbedaan dari pola gerak tari Bedhaya Bedhah Madiun di Mangkunegaran dan Kasultanan Yogyakarta adalah pada teknik pelaksanaannya. Di Mangkunegaran aksentuasi dari pola gerak lebih sedikit dan terkesan lentur, sedangkan di Yogyakarta terkesan patah-patah.

Berdasar informasi di atas timbul pertanyaan mengenai alasan Mangkunegaran memiliki tari Bedhaya Bedhah Madiun gaya Yogyakarta. Mangkunegaran yang merupakan bagian dari Kasunanan Surakarta, berdasar pada tradisi menggunakan tari gaya Surakarta. Pada masa pemerintahan Mangkunegara VII di Mangkunegaran terdapat tari Bedhaya Bedhah Madiun dengan gaya Yogyakarta. Dari pertanyaan yang diajukan, kajian ini bertujuan mendeskripsikan faktor keberadaan tari gaya Yogyakarta di Mangkunegaran, dengan memilih studi kasus pada tari Bedhaya Bedhah Madiun.

Analisis masalah menggunakan konsep penyebaran unsur-unsur kebudayaan oleh Koentjaraningrat. Penyebaran unsur-unsur kebudayaan dapat didasarkan atas pertemuanpertemuan antara individu dalam suatu kelompok manusia dengan individu kelompok tetangga. Pertemuan antara berbagai kelompok-kelompok semacam itu dapat berlangsung dengan berbagai cara (Koentjaraningrat, 2015:199). Salah satu cara pertemuan adalah melalui sebuah pernikahan. Berdasar pada studi Brandon (1989: 28) dan Holt (2000: 31), dapat diketahui bahwa melalui pernikahan antara orang India dengan pemimpin lokal unsur-unsur kebudayaan India mulai masuk ke Indonesia. Menurut R.M. Soedarsono (1979: 
87), tari Jawa memengaruhi tari Bali pada masa Hindu-Jawa Timur sejak adanya perkawinan antara putri Kerajaan Kahuripan dengan Raja Udayana. Kajian Kusmayati (1988: 81) dan Soemaryatmi (1998: 62) menerangkan, bahwa pernikahan Sri Paku Alam VII dengan putri Sri Susuhunan Paku Buwana X merupakan titik tolak keberadaan tari bedhaya gaya Surakarta di Paku Alaman. Dari beberapa pendapat tersebut peneliti berasumsi bahwa Mangkunegaran memiliki tari Bedhaya Bedhah Madiun karena pernikahan K.G.P.A.A. Mangkunegara VII dengan putri Sri Sultan Hamengku Buwana VII.

Studi tari Bedhaya Bedhah Madiun sudah banyak dilakukan, namun yang secara spesifik menganalisis faktor keberadaan tari Bedhaya Bedhah Madiun gaya Yogyakarta di Mangkunegaran belum dilakukan. Munarsih (2010) membahas tentang kedudukan tari Bedhaya Bedhah Madiun di Mangkunegaran. Tari ini digunakan untuk melegitimasi kekuasaan K.G.P.A.A. Mangkunegara VII. Kusumo (2015) mendeskripsikan tari Bedhaya Bedhah Madiun gaya Yogyakarta hasil rekonstruksi Kadaryati. Kusumo mendeskripsikan tari Bedhaya Bedhah Madiun dengan menganalisis motif gerak, pola lantai, dan kostum. Rohmawati (2016) membahas tentang nilai estetik tari Bedhaya Bedhah Madiun. Dari beberapa kajian itu dapat diketahui, bahwa kajian faktor keberadaan tari Bedhaya Bedhah Madiun Gaya Yogyakarta di Mangkunegaran belum dilakukan. Dengan demikian, keaslian kajian ini dapat dipertanggungjawabkan.

Kajian lain yang terkait dengan hal ini adalah studi yang dilakukan oleh Suharti (1990). Suharti telah mengungkapkan pengaruh tari gaya Yogyakarta di Mangkunegaran pada masa pemerintahan K.G.P.A.A. Mangkunegara VII. Pengaruh itu terjadi karena adanya hubungan pernikahan antara Mangkunegara VII dan G.K.R. Timur. Suharti menekankan bahwa hubungan pernikahan antara pihak Mangkunegaran dan Kasultanan Yogyakarta menjadi faktor keberadaan tari Gaya Yogyakarta di Mangkunegaran. Akan tetapi, Suharti kurang memerhatikan faktor lain dari keadaan sosial politik Mangkunegaran yang menyebabkan terjadinya hubungan pernikahan tersebut dan penyerapan tari gaya Yogyakarta dengan memilih karya tari dalam genre bedhaya dan srimpi.

\section{Metode}

Kajian ini merupakan kajian kualitatif dengan pendekatan etnokoreologi yang menekankan peng-kajian terhadap budaya tari etnik non-Barat berdasar teks kebudayaan yang melahirkan budaya tari tersebut (Suharti, 2015:30). Artinya, kehadiran tari tidak lepas dari sebuah konteks, karena tari merupakan teks budaya masyarakat setempat. Pendekatan etnokoreologi dibentuk dari landasan pemikiran yang dipinjam dari berbagai disiplin. Pendekatan ini mengandalkan data kualitatif yang didominasi oleh studi pustaka dan etnografi tari (Pramutomo, Joko, dan Mulyana, 2016:17-18).

Studi pustaka dan studi arsip digunakan untuk mendeskripsikan faktor keberadaan tari Bedhaya Bedhah Madiun di Mangkunegaran. Metode penelitian arsip adalah metode yang melibatkan studi dokumen sejarah, yaitu dokumen yang dibuat di beberapa titik pada masa lalu, memberikan informasi mengenai sebuah organisasi (negara, istana, kelompok seni, dan sebagainya), individu, dan kegiatan-kegiatan pada masa itu. Artinya arsip dapat digunakan sebagai sumber data untuk mengetahui peristiwa masa lalu (Ventresca dan Mohr, 2002: 1-4).

Sumber data yang digunakan dalam artikel ini adalah arsip atau dokumen yang tersimpan di Mangkunegaran (catatan karya seni yang dimiliki, surat, piagam, laporan kerja, dan sebagainya), biografi, surat kabar, majalah, artikel jurnal, literatur akademik (buku dan laporan penelitian). Selain dokumen yang bersifat narasi atau teks, gambar (foto dan video) juga menjadi sumber data dalam metode penelitian arsip. Endter (2000: 2021) berpendapat bahwa gambar merupakan dokumentasi dari pengalaman yang menyatakan bahwa peristiwa tersebut benar-benar terjadi. Menurutnya, gambar merupakan sebuah memori kolektif yang dapat digunakan untuk mengetahui kehidupan masyarakat pada masa lalu.

\section{Latar Belakang Kehidupan Mangkunegara VII}

\section{Genealogi dan Sosialisasi}

Mangkunegara VII memiliki nama kecil B.R.M. Surya Suparto. Garwa ampil Mangkunegara V, B.R. Purnamaningrum melahirkan Suparto pada 12 November 1885 atau dalam tahun Jawa bertepatan pada Kamis Wage, 3 Sapar tahun Dal 
1815. Suparto adalah anak ketujuh dan merupakan putra laki-laki ketiga dari Mangkunegara V (Darmawan, 2006:4). Sejak kecil Suparto diberikan kepada R.M. Suyitno untuk diangkat sebagai putranya, sehingga pengasuhan dan pendidikan dilakukan oleh keluarga Suyitno. Sikap disiplin dan inovatif yang dimiliki Suyitno tentunya berpengaruh pada kepribadian Suparto (Wasino, 1994:83).

Pada 1896 Mangkunegara V wafat, kemudian digantikan oleh R.M. Suyitno dengan gelar K.G.P.A.A. Mangkunegara VI (1896-1916). Ketika naik tahta, Mangkunegara VI dihadapkan pada kerusakan ekonomi Mangkunegaran. Kerusakan ekonomi disebabkan oleh beberapa faktor, yaitu (1) pada masa pemerintahan Mangkunegara V terjadinya krisis ekonomi dunia yang memengaruhi perekonomian Mangkunegaran, (2) kemunculan hama tanaman yang merusak perkebunan Mangkunegaran, dan (3) kesalahan manajemen yang dilakukan oleh Mangkunegara V (Wasino, 1994:74).

Mangkunegara VI melakukan penghematan dalam segala bidang dan menerapkan hidup sederhana untuk memulihkan perekonomian (Anonim, 1996:3-4). Penerapan politik penghematan Mangkunegara VI berdampak pada pembatasan pendidikan para pangeran. Mangkunegara VI membatasi pendidikan para pangeran dengan studi paling tinggi di Europesche Lagere School (ELS). Penetapan pembatasan pendidikan memengaruhi studi Suparto, yang berharap dapat melanjutkan studi di Hogere Burger School (HBS). Antusiasnya untuk melanjutkan studi ke jenjang lebih tinggi ditolak oleh Mangkunegara VI. Penolakan itu menyebabkan Suparto meninggalkan Mangkunegaran pada 1902 (Anonim, 1986:13; Darmawan, 2006: 7; Wasino, 1994: 85-86).

Suparto meninggalkan Mangkunegaran dengan bekal minimum dan ditemani oleh seorang abdi dalem. Suparto melamar dan bekerja di luar istana, serta manjelajahi seluruh Pulau Jawa dengan berjalan kaki atau naik kereta kelas 3, dan sering menginap di rumah kepala desa atau warga. Pengalaman perjalanan tersebut menimbulkan kepekaan terhadap lingkungan sosial yang berpengaruh pada pandangan hidup dan sikapnya ketika menjadi pemimpin Mangkunegaran (Singgih, 1986: 22-23).

Suparto dalam perantauannya sangat giat dalam belajar, bekerja, serta berkenalan dengan orang-orang Belanda dan pribumi di luar istana. Suparto meskipun hanya lulus dari Sekolah Rendah Eropa, tetapi memiliki semangat belajar yang sangat tinggi. Berdasar pidato M.J.J. Treur (1987: 2-3), Suparto sangat rajin dalam belajar bahasa Belanda dan kesusastraan Jawa. Kepandaian berbahasa Suparto memberikan kemudahan dalam berkomunikasi, sehingga dapat mendekatkan diri kepada Belanda dan masyarakat Jawa (Singgih, 1986: 25). Hal itu di kemudian hari tentunya sangat berpengaruh pada kedudukan dan gaya kepimimpinan Suparto di Mangkunegaran.

Pada 20 Maret 1911, Suparto diangkat menjadi juru bahasa sementara (adjunct translateur) di Kantor Juru Bahasa Surakarta. Residen Surakarta G.F. van Wijk (1909-1914) memberikan perhatian khusus pada Suparto, karena etos kerjanya yang baik. Selain menjadi penerjemah, Suparto juga aktif dalam organisasi Budi Utomo dan sebagai korespondensi dari harian Jawa Darmo Kondo. Pekerjaan baru ini banyak memengaruhi relasi Suparto baik dengan orang Belanda maupun pribumi, sehingga dapat memperluas pandangan dan gagasannya (Anonim, 1987a:3-4).

Pandangan demokratis Suparto serta kepandaian dalam berkomunikasi dan berpenampilan simpatik memberikan kesan baik kepada Mr. C. Th. van Deventer. Atas bantuan Deventer, Wijk, dan J.H. Abendanon pada 4 Juni 1913 Suparto dapat berangkat ke Belanda dengan dana pribadinya (Anonim, 1987a:4; Muhlenfeld, 1989:30; Singgih, 1986:24-25). Suparto ke Belanda bertujuan untuk memperluas pandangan dan memperdalam studinya. Suparto belajar sastra di Fakultas Kesusastraan Timur Universitas Leiden (Hermono, 2014:24).

Pada saat libur akademik, Suparto mengikuti latihan kemiliteran sebagai cadangan, yang kemudian karena Perang Dunia I harus tetap mengikuti pelatihan tersebut (Singgih, 1986:25). Suparto diterima sebagai sukarelawan pada Sekolah Kader Cadangan pada 27 Desember 1913. Berdasar Surat Kapten yang bertugas memimpin kursus-kursus Militer Provinsi Zuid-Holland 27 
Februari 1914 No. 161 LI Suparto menerima panggilan untuk mengikuti Kursus Musim Dingin bagi Kader Cadangan. Pada 23 Maret 1915 Suparto diangkat menjadi bintara dan berdasar Surat Keputusan Ratu Belanda 7 Mei 1915 diangkat menjadi Letnan Dua Cadangan bagian Infanteri yang ditempatkan di Resimen Grenadiers (Anonim, 1989:1-2). Melalui kedudukannya itu Suparto mulai dikenal Ratu Belanda, yang berpengaruh pada pengangkatannya sebagai pemimpin Mangkunegaran (Wasino, 1994:92).

Suparto kembali dari Belanda pada Juni 1915. Sesampainya di Surakarta, Suparto aktif dalam organisasi Budi Utomo. Suparto menggantikan Radjiman Wedyodiningrat menjadi presiden Budi Utomo pada Juli 1915. Selain itu, ia juga aktif kembali dalam surat kabar Darmo Kondo. Berdasar Surat Keputusan Direktur Pangreh Praja (Binnenlandsch Bestuur) 5 Oktober 1915 No. 1318, Suparto diangkat menjadi Ajun Kontrolir urusan agraria di wilayah Mangkunagaran. Jabatan tersebut hanya berlangsung lima bulan, karena setelah itu Suparto menggantikan Mangkunegara VI memimpin Mangkunegaran. Kedudukkan Suparto yang terakhir menyebabkannya harus melepas jabatan Ketua Budi Utomo pada Juni 1916 dan berhenti dari anggota militer pemerintah Belanda (Anonim, 1989:2; Darmawan, 2006:25; Sunarmi, 2005:35; Wasino, 1994:94).

Pendidikan dan riwayat pekerjaan Suparto di atas tentunya sangat berpengaruh dalam kepemimpinannya di Mangkunegaran. Sikap domokratis yang didukung kemampuan komunikasi serta etos kerja yang baik dapat memperbanyak relasi Suparto, sehingga memperluas padangan dan gagasannya. Pandangan dan gagasan Suparto yang luas menjadikannya sebagai pemimpin yang modern serta berpikiran kritis (Larson, 1990:103; Suharti, 1990:40-41). Hal itu tentunya memengaruhi perkembangan seni di Mangkunegaran.

\section{Pergantian Pemerintahan K.G.P.A.A. Mangkunegara VI ke K.G.P.A.A. Mangkunegara VII}

Mangkunegara VI menanggapi perekonomian Mangkunegaran yang rusak dengan melakukan politik penghematan. Mangkunegara VI melakukan penghematan dalam segala bidang dengan meniadakan pengeluaran yang dianggap tidak berguna. Mangkunegara VI menerapkan cara hidup sederhana dengan jarang melakukan pesta, yang umumnya secara tradisional digunakan untuk menunjukkan kewibawaan kaum aristokrat (Anonim, 1996:3-4). Hal tersebut diasumsikan menjadi faktor penghambat perkembangan kesenian pada masa Mangkunegara VI.

Politik penghematan yang diterapkan Mangkunegara VI mampu memperbaiki perekonomian Mangkunegaran. Pada 1899 Mangkunegara berhasil melunasi utangnya kepada Belanda dan bahkan dapat mengisi kas negara yang semula kosong. Pangreh Praja Belanda yang dibentuk untuk mengawasi keuangan Mangkunegaran ketika mengalami kerusakan ekonomi tidak lagi melakukan tugasnya, karena dianggap keadaan perekonomian sudah sangat baik. Mangkunegara VI dianggap sebagai ahli keuangan karena keberhasilannya tersebut (Anonim, 1996:2-5; Darmawan, 2006:26; Metz, 1987:7).

Gaya hidup hemat dan sederhana yang bertentangan dengan gaya hidup para bangsawan, menyebabkan politik penghematan Mangkunegara VI banyak mendapatkan respons negatif. Puncak dari dampak politik penghematan Mangkunegara VI adalah pengiriman petisi kepada pemerintah Hindia Belanda pada Januari 1908. Petisi tersebut berisi permohonan supaya gelar kebangsawanan dari putra Mangkunegara VI dicabut. Petisi itu dibuat oleh enam pangeran Mangkunegaran yang di antaranya adalah putra Mangkunegara V. Para pengeran tersebut tidak suka terhadap pengawasan yang sangat ketat terhadap kas Mangkunegaran, serta keprihatinan mengenai pewaris tahta Mangkunegaran (Larson, 1990:96). Para pangeran berharap ketika putra Mangkunegara VI dicabut gelar kebangsawanannya, maka tidak dapat mewarisi tahta ayahnya. Menurut hemat penulis, pengiriman petisi ini bertujuan untuk mengkudeta pemerintahan Mangkunegara VI dengan menghapus pewaris tahtanya.

Berdasar penyelidikan pemerintah Hindia Belanda, putra Mangkunegara VI lahir dari seorang pelayan tingkat rendah serta tidak memiliki kejelasan mengenai kelahirannya. Melalui surat rahasia, Gubernur Jenderal Hindia Belanda memutuskan bahwa R.M. Suyono sebagai anak tiri Mangkunegara VI. Jadi, Suyono tidak berhak 
menjadi pewaris tahta Mangkunegaran (Larson, 1990:96). Keputusan Gubernur Jenderal membuat penurunan kewibawaan Mangkunegara VI di keluarganya, sehingga kedudukan sebagai kepala keluarga Mangkunegaran sulit untuk dipertahankan. Antara Mangkunegara VI dengan para pangeran pengirim petisi muncul kebencian. Menurut laporan van Wijk Mangkunegara VI jatuh sakit dan sering menyendiri, bahkan mengancam untuk mengakhiri hidupnya. Residen Surakarta Sollewijn Galpke (1914-1918) mengatakan bahwa keadaan yang paling memalukan dan menyakitkan hatinya adalah keputusan gubernemen untuk mengeluarkan Suyono sebelum Mangkunegara VI wafat. Hal itu yang kemudian mendorong Mangkunegara VI untuk mengundurkan diri dari jabatannya. Mangkunegara VI bertemu dengan Gelpke dan memutuskan untuk mengundurkan diri pada 27 Agustus 1914. Pada 11 Januari 1915 Gubernur Jenderal Hindia Belanda menyetujui keinginannya dengan syarat menunggu satu tahun untuk mencari penggantinya (Anonim, 1996: 4; Larson, 1990: 96-97; Metz, 1987: 7).

Mangkunegara VI beserta keluarga pada Januari 1916 dengan diam-diam pergi dan menetap di Surabaya. Mangkunegara VI pergi sebelum pelaksanaan perpisahan yang direncanakan dengan resepsi besar-besaran. B.R.Ay. Partini menyatakan bahwa setelah Mangkunegara VI turun tahta, banyak orang yang membicarakan mengenai penggantinya, kondisi Mangkunegaran tampak sunyi dan suram (Singgih, 1986:36).

Pada 1915 terdapat tiga putra Mangkunegara III, dua putra Mangkunegara IV (1853-1881), dan tiga belas putra Mangkunegara $\mathrm{V}$ yang dapat dipertimbangkan menjadi pengganti Mangkunegara VI. Pangeran yang dipilih oleh Residen Surakarta, Penasihat Urusan Bumiputra, Direktur Pemerintahan Dalam Negeri, dan mayoritas anggota Dewan Hindia Belanda adalah seorang putra dari Mangkunegara IV. Seorang anggota Dewan Hindia Belanda, Mr. A.C.D. de Greaff menyatakan pandangan yang menentang pendapat mayoritas. Greaff menyatakan bahwa putra dari Mangkunegara IV tersebut tidak memiliki kemampuan untuk memimpin Mangkunegaran. Gubernur Jendral A.W.F. Indeburg (1909-1916) terpengaruh oleh pendapat Greaff dan kemudian Suparto yang dipilih sebagai pengganti Mangkunegara VI (Larson, 1990:9798).

Keterpilihan Suparto sebagai pengganti Mangkunegara VI tidak lepas dari dukungan politikus Belanda C. Th. van Deventer dan mantan Residen Surakarta G.F. van Wijk. Pemerintah Hindia Belanda meyakini pendapat Deventer dan Wijk mengenai kemampuan Suparto untuk menjalankan Politik Etis yang sedang diterapkan Belanda (Darmawan, 2006: 26; Lelyveld, 1989: 75). Pada 15 Februari 1916 Suparto menandatangani Akta van Verband, dengan syarat mengundurkan diri dari Ketua Budi Utomo, Ajun Kontrolir sementara Urusan Agraria, dan tentara Cadangan Belanda (Anonim, 1989:2; Larson, 1990:98). Suparto secara resmi menjadi pemimpin Mangkunegaran dengan gelar K.G.P.A.A. Prabu Prangwedana VII pada 3 Maret 1916. Pada 4 September 1924 ditetapkan menjadi K.G.P.A.A. Mangkunegara VII Kolonel Komandan Legiun Mangkunegaran ing Surakarta (Anonim, t.t.:1-2).

Banyak orang yang tidak mengira bahwa Suparto terpilih sebagai pemimpin Mangkunegaran, karena menjadi calon kelima atau keenam (Muhlenfeld, 1989:31). Residen Surakarta F.P. Sollewijn Gelpke (1914-1918) dan penggantinya yaitu A.J.W. Harloff (1918-1922) memiliki hubungan tidak baik dengan Mangkunegara VII. Gelpke menentang pengangkatan Suparto menjadi pemimpin Mangkunegaran. Gelpke berpendapat, bahwa Suparto adalah penghasut para pangeran untuk mengirim petisi tentang putra Mangkunegara VI. Menurut Harloff, Suparto adalah seorang pemuda Jawa yang progresif dengan banyak kekurangan. Suparto terlalu cepat menyimpulkan dengan pengalaman dan pengetahuan yang kurang mendalam. Suparto dianggap ingin dilihat oleh masyarakat umum tidak hanya memajukan Mangkunegaran, tetapi juga membentuk sebuah negara ideal. Suparto merupakan orang yang mudah dirayu dan dimanfaatkan untuk menghasut pemerintah Belanda. Penasihat Urusan Bumiputra, D.A. Rinkes berkeberatan dengan keputusan Suparto menjadi pemimpin Mangkunegaran. Rinkes memiliki kekhawatiran karena Suparto merupakan seorang pemimpin nasionalis muda, yang akan mengepalai sebuah praja dengan kekayaannya (Larson, 1990:100-103). Menurut penulis, pada 
dasarnya para pejabat Belanda yang menolak pengangkatan Suparto memiliki rasa khawatir akan kemampuannya untuk melawan Belanda.

Pengunduran diri Mangkunegara VI membuat kondisi sosial politik Mangkunegaran kurang stabil. Sebagai pewaris, Mangkunegara VII harus mampu menunjukkan kemampuan dalam memimpin Mangkunegaran. Dalam pidato pengangkatan Suparto menjadi Mangkunegara VII, Residen Surakarta Sollewijn Gelpke menyatakan bahwa:

"Ing Mangkunegaran wonten sadhiyan bandha cekap, saged katanjakaken dados sarana kamajenganing praja lan kawula, miturut karsa lan keyakinan panjenengan..." Punika wonten wangsulan-dalem ingkang mungel: "Sasampunipun setaun, bénjing kénging dipun tingali”(Anonim, 1986:16).

Terjemahan:

"Mangkunegaran memiliki banyak dana yang cukup untuk memajukan negara dan rakyat, berdasarkan kehendak dan keyakinan Paduka...” Ini jawaban dari Paduka yang berbunyi: "Setelah satu tahun, akan dapat dilihat."

Residen Surakarta yang pada dasarnya memiliki hubungan tidak baik dengan Mangkunegara VII, dalam pidatonya seperti memberikan sebuah tantangan. Tanggapan Mangkunegara VII terhadap sikap residen adalah dengan melakukan banyak pembangunan, di antaranya dalam bidang pendidikan, olah raga, penyiaran radio (Solosche Radio Vereeniging), kesehatan, pertanian, pembaharuan instalasi pabrik gula, pembuatan jalan dan jembatan, pembangunan kantor dinas, pendirian Bank Desa, pendirian Java Instituut (1919), dan Studi Kring (Studi Kebudayaan dan Filsafat) (1931), serta pengembangan kesenian (Anonim, 1986:16-19, Anonim, t.t.:3-5; Darmawan, 2006:28-51; Metz, 1987:78-80). Tindakan Mangkunegara VII tersebut berhasil memenuhi harapan pemerintah Hindia Belanda. Pada akhir 1931 Mangkunegara VII mendapatkan gelar Zijne Hoogheid, serta ketika berusia 50 tahun diangkat menjadi ajudan Ratu Belanda (Metz, 1987:8).
Hubungan Sosial Politik Kasunanan Surakarta dan Mangkunegaran Akhir Abad XIX-Awal Abad XX

Bagi Mangkunegara I, Perjanjian Salatiga telah mengagalkan cita-citanya untuk menjadi raja, maka untuk memperkuat kekuasaannya menggunakan politik pernikahan, ekonomi, dan secara bergantian mendekatkan diri dengan Sunan serta Belanda. Politik pendekatan diri dengan Belanda menyebabkan Mangkunegaran menjadi pion dalam struktur politik yang terpecah belah di Jawa. Dampak dari peran positif Mangkunegaran sebagai pion Belanda adalah mulai kuatnya kedudukan Mangkunegaran di Jawa dengan pembentukan legiun, perluasan wilayah, dan akta pengikat (Houben, 1989:9-13).

Pada masa Mangkunegara I (1757-1796) dan Mangkunegara II (1796-1833) akta pengikat sebagai dasar pengangkatan mereka menunjukkan bahwa Mangkunegara menjadi kawula Susuhunan dan Belanda. Kedudukan Susuhunan di Mangkunegaran mulai berkurang sejak masa pemerintahan Mangkunegara III (1833-1853). Dalam akta pengikat Mangkunegara I dan II tertulis bahwa pengangkatan mereka "atas kebaikan hati Pemerintah Hindia Belanda dan Susuhunan", sedangkan pada akta pengikat Mangkunegara III tertulis bahwa pengangkatannya "atas kebaikan hati Pemerintah Hindia Belanda dengan sepengetahuan Susuhunan." Mulai Mangkunegara VI rumusan "dengan sepengetahuan Susuhunan" tidak disebutkan dalam akta pengikat. Artinya, Mangkunegara VI diangkat dan bertanggung jawab kepada pemerintah Hindia Belanda. Jadi, secara politis Mangkunegara VI sudah tidak terikat dengan Susuhunan (Houben, 1989:12-13; Metz, 1987:47; Wasino, 1994:73-74).

Kedudukan Mangkunegaran yang merdeka dari Kasunanan Surakarta mendapat respons negatif dari Sri Susuhunan Paku Buwana X (18931939). Susuhunan Paku Buwana X menganggap bahwa secara politis Mangkunegaran tidak terikat dengan kekuasaannya, tetapi secara kultural tetap terikat dengan Kasunanan. Mangkunegaran hanya replika dari kebudayaan Jawa, sedangkan Kasunanan Surakarta adalah pusat kebudayaan Jawa di Surakarta. Hal itu ditunjukkan dari tradisi kenegaraan di Mangkunegaran, seperti bahasa, busana, etika, pengelolaan praja, serta upacara 
kenegaraan yang hampir sama dengan Kasunanan Surakarta (Wasino, 1994:79-80). Selain itu, gaya tari yang digunakan di Mangkunegaran pada dasarnya adalah tari gaya Surakarta.

Sikap Susuhunan Paku Buwana X yang tidak rela atas kemerdekaan Mangkunegaran diimplementasikan dalam tindakan-tindakannya, terutama pada masa Mangkunegara VII yang sedang berusaha mengembangkan kebudayaan Jawa. Kedekatan Mangkunegara VII dengan Belanda dimanfaatkan oleh Susuhunan Paku Buwana $\mathrm{X}$ dengan menggerakkan organisasiorganisasi kebangsaan yang bersifat radikal dan nonkooperatif terhadap Kolonial untuk mengkritik Mangkunegara VII. Hal itu dilakukan, karena Susuhunan Paku Buwana X merasa iri atas kemajuan Mangkunegaran dari segi politik maupun kemakmuran. Susuhunan Paku Buwana X merasa disaingi oleh sebuah kadipaten, yang pada mulanya merupakan vasal (Wasino, 1994:97).

Tindakan lain yang dilakukan Susuhunan Paku Buwana X adalah ketidakhadirannya pada setiap kongres pengembangan budaya melalui Java Instituut yang diprakarsai oleh Mangkunegara VII. Pengembangan budaya yang dilakukan oleh Mangkunegara VII kiranya tidak mendapatkan simpati dari Susuhunan Paku Buwana X, sebab dapat meningkatkan kewibawaan Mangkunegaran (Sunarmi, 2005:45). Dalam pandangan raja atau para bangsawan Jawa, kebudayaan adiluhung mencerminkan kekuasaan, kemegahan, serta kebesaran, yang dapat memperkokoh kedudukannya (Kartodirdjo, dkk., 1987:53-56; Soedarsono, 2003:74; Soeratman, 1989:119). Jadi, apabila Mangkunegaran dapat mengembangkan kebudayaan, maka dapat memperkuat statusnya sebagai sebuah kadipaten yang merdeka dari Kasunanan Surakarta. Melalui kebudayaan, Susuhunan Paku Buwana $\mathrm{X}$ ingin mempertahankan kedudukan, yang secara tradisional sebagai puncak hierarki strata sosial di Surakarta.

\section{Pernikahan K.G.P.A.A. Mangkunegara VII dengan G.K.R. Timur}

K.G.P.A.A. Mangkunegara VII memilih B.R.Aj. Mursudariyah sebagai permaisuri. Mursudariyah adalah putri ke-12 dari Sri Sultan Hamengku Buwana VII dengan permaisuri ketiga G.K.R.
Kencana. Mursudariyah merupakan adik kandung dari B.R.Aj. Mursudarinah dan B.R.M. Sugiri atau G.P.H. Tejokusumo. Mursudarinah menjadi permaisuri kedua Sri Susuhunan Paku Buwana X dengan gelar G.K.R. Hemas pada Oktober 1915. G.P.H. Tejokusumo adalah salah satu pelopor pendirian Kridha Beksa Wirama (KBW). Tejokusumo sangat berpengaruh dalam perkembangan tari di Mangkunegaran. Setelah menikah dengan Mangkunegara VII, Mursudariah oleh Sultan Hamengku Buwana VII diberi nama G.K.R. Timur (Hermono, 2014:29).

Pernikahan Mangkunegara VII dan Gusti Timur dilaksanakan di Keraton Kasultanan Yogyakarta pada 6 September 1920. Selayaknya pernikahan putri Sultan yang lahir dari permaisuri, pernikahan Mangkunegara VII dan Gusti Timur berlangsung mewah, serta kaya adat istiadat yang berlaku. Pada 14 September 1920 Gusti Timur diboyong ke Mangkunegaran dengan menggunakan kereta api Ekspress. Mangkunegara VII dan Gusti Timur dari Stasiun Balapan menuju Mangkunegaran menggunakan Kereta Kyai Candrakantha. Pesta pernikahan di Mangkunegaran berlangsung meriah. Dalam pesta pernikahan, di Pendapa Mangkunegaran dipertunjukkan wayang orang, pesta dansa, dan tari Bali. Tari Bali merupakan persembahan dari Raja Karangasem Bali, Ida Anak Agung Bagus Djlantik. Selain itu, di depan pura diselenggarakan pemutaran film dan lomba untuk masyarakat (Djlantik, 1989:201; Hermono, 2014:30-31; Singgih, 1986:63-65).

Dalam literatur "Pangeran Adipati Aria Mangkunegara VII dan Gusti Kanjeng Ratu Timur dari Yogyakarta, suatu Pernikahan Raja Jawa” terbitan Rekso Pustoko (Anonim, 1987b:3-4), dijelaskan bahwa Pernikahan Mangkunegara VII dan Gusti Timur memiliki arti kultural dan historis. Memiliki arti kultural karena dipergelarkan berbagai bentuk kesenian dalam pesta perayaannya. Memiliki arti historis karena lebih dari satu abad antara Mangkunegaran dan Kasultanan Yogyakarta tidak ada hubungan pernikahan. Hal ini berawal dari perselisihan Sri Sultan Hamengku Buwana I (1755-1792) dengan Mangkunegara I, yang menyebabkan Mangkunegara I berkeinginan sampai dengan generasi ketujuh tidak diadakan hubungan pernikahan dengan Kasultanan 
Yogyakarta. Sumpah tersebut didasarkan atas harapan Sultan Hamengku Buwana I untuk tidak wafat lebih dulu, karena khawatir kekuasaannya akan dibagi dua yaitu untuk Kasunanan Surakarta dan Mangkunegaran. Mangkunegara II sampai dengan Mangkunegara VI telah memegang teguh janji tersebut, tetapi Mangkunegara VII telah memulihkan hubungan dengan menikahi salah satu putri Sultan.

Para bupati atau adipati pada umumnya melakukan pernikahan dengan keluarga kerajaan untuk memperkuat statusnya (Kartodirdjo, dkk., 1987:179). Hal tersebut dilakukan oleh para adipati di Mangkunegaran. Keluarga Mangkunegara menjalin hubungan pernikahan dengan keluarga Susuhunan di Surakarta, khususnya ketika keberadaannya secara politis masih di bawah Kasunanan Surakarta (Anonim, 1986:21-22). Putra sulung Mangkunegara I, dinikahkan dengan putri Susuhunan III yang bernama Kanjeng Ratu Alit. Istri Mangkunegara II, Raden Ayu Gugu adalah anak dari patih Surakarta yang bernama Raden Adipati Sindurejo. Mangkunegara III pada 1823 menikah dengan saudara Susuhunan VI. Mangkunegara III juga merencanakan pernikahan dengan putri tunggal dari permaisuri Susuhunan VII yang bernama Raden Ayu Sekar Kedaton. Melalui pernikahan itu, Mangkunegara III berharap dapat menggantikan Susuhunan yang belum memiliki putra mahkota. Rencana Mangkunegara III ini tidak berhasil, sebab lamarannya ditolak oleh pihak Kasunanan. Permaisuri Susuhunan IX merupakan kemenakan Mangkunegara IV. Permaisuri Susuhunan IX adalah putra K.P.H. Hadiwijaya II, sedangkan Mangkunegara IV merupakan adik Hadiwijaya II. Putri Mangkunegara IV, adik Mangkunegara V menjadi permaisuri pertama Susuhunan X, yang bernama G.K.R. Paku Buwana (Houben, 1989:14; Soeratman, 1989:52-54).

Mangkunegara VII memperkuat kedudukannya dengan mengambil permaisuri dari putri Sri Sultan Hamengku Buwana VII (1877-1921). Hal tersebut dilakukan karena menanggapi keadaan sosial politik yang kurang baik dengan Kasunanan Surakarta. Keadaan tersebut disebabkan oleh sikap Susuhunan Paku Buwana X yang tidak rela atas kemajuan politik dan kemakmuran Mangkunegaran. Sikap Susuhunan Paku Buwana $\mathrm{X}$ berdampak negatif dalam pengembangan budaya yang diprakarsai Mangkunegara VII. Melalui politik pernikahan ini Mangkunegara VII berharap dapat mendekatkan diri dengan Kasultanan, sehingga mendapatkan dukungan untuk mengembangkan kebudayaan Jawa. Kasultanan Yogyakarta dipilih karena merupakan pewaris dari Kerajaan Mataram Islam, yang menjadi pusat pengembangan budaya Jawa di Yogyakarta. Secara tradisional, Kasultanan Yogyakarta merupakan puncak hierarki strata sosial pemerintahan di Jawa, yang sejajar dengan Kasunanan Surakarta. Interpretasi ini didasarkan pada fakta setelah adanya pernikahan antara pihak Mangkunegaran dan Kasultanan Yogyakarta, absorpsi karya tari gaya Yogyakarta di Mangkunegaran, dan didirikan kantor serta museum Java Instituut di Yogyakarta.

\section{Pengembangan Seni Tari di Mangkunegaran pada Masa Pemerintahan K.G.P.A.A. Mangkunegara VII}

\section{Gagasan Mangkunegara VII}

Dalam memajukan Mangkunegaran, salah satu tindakan Mangkunegara VII adalah mengembangkan kebudayaan. Mangkunegara VII berpendapat bahwa diperlukan pengenalan budaya Jawa ke Belanda, untuk menunjukkan bahwa Jawa pada dasarnya memiliki peradaban yang besar (Darmawan, 2006: 29; Hermono, 2014: 78-79). Gaya kepemimpinan Mangkunegara VII yang demokratis, modern, dan memiliki pandangan serta gagasan luas menyebabkan Mangkunegaran menjadi salah satu pusat pengembangan kebudayaan Jawa (Muhlenfeld, 1989:31). Dalam mengembangkan kebudayaan Jawa, Mangkunegara VII mempelajari dan mengambil nilai-nilai positif dari kebudayaan Barat, namun tetap mempertahankan pandangan dan gagasan masyarakat Jawa (Cannegieter, 1986:7-17). Mangkunegara VII memiliki kepedulian terhadap hubungan budaya antardaerah, antaristana, serta apresiasi terhadap kebudayaan antarbangsa (Soeryosoeyarso dan Darmawan, 1992:9).

Dalam mengembangkan kebudayaan, kesenian menjadi salah satu pusat perhatian Mangkunegara VII (Wedyodiningrat, 1944:1). Mangkunegara VII memiliki pandangan bahwa pembangunan kembali bangsa Jawa dapat didasarkan pada sejarahnya yang agung 
(Muhlenfeld, 1989:29). Pandangan tersebut direalisasikan melalui pengumpulan produkproduk unggulan dari kesenian Jawa Kuna untuk dijadikan sumber inspirasi pada karya seninya. Pencarian produk tidak hanya di wilayah Mangkunagaran, namun sampai ke daerah Cirebon, Jawa Timur, Madura, dan Bali (Stutterheim, 1989:51).

Gaya kepemimpinan Mangkunegara VII yang demokratis, modern, dan memiliki pandangan serta gagasan luas memengaruhi perkembangan seni di Mangkunegaran. Gaya kepemimpinan Mangkunegara VII tersebut menyebabkan bentuk kesenian dari luar yang memiliki koherensi dengan kebudayaan Jawa dapat diterima. Kesenian tersebut diserap kemudian diinovasi sesuai dengan keadaan sosial budaya Mangkunegaran. Salah satu contohnya adalah penyerapan karya tari gaya Yogyakarta yang dipelajari melalui KBW. Selain itu adalah penyerapan beberapa asesoris dari Cirebon dan Bali untuk kostum tari di Mangkunegaran. Misalnya, dari Cirebon Mangkunegara VII menyerap tekes yang digunakan untuk tari Bandabaya, jamang untuk tari Sari Tunggal, tari Bedhaya Bedhah Madiun, tari Srimpi Pandhelori, dan tari Srimpi Muncar, sedangkan dari Bali adalah kalung kace yang digunakan oleh prajurit kera (kethek kenyung).

\section{Peranan G.K.R. Timur dalam Pengembangan Seni di Mangkunegaran}

Gusti Timur sebagai permaisuri selalu mendampingi, mendukung, dan memberi masukan dalam pengembangan seni di Mangkunegaran. Dukungan dan masukan Gusti Timur diterima oleh Mangkunegara VII dengan kebijaksanaannya (Hermono, 2014:33). Gusti Timur sebagai putri Sultan (penggambaran ini dapat dilihat pada Gambar 1) memiliki jiwa seniman, didasari dari pendidikannya di Keraton Kasultanan Yogyakarta. Dalam "Serat Lelampahan Dalem Suwargi K.G.P.A.A. Mangkunegara VII ing Surakarta” (Anonim, t.t.:4), dinyatakan bahwa Mangkunegara VII didampingi permaisuri (Gambar 2), setiap Rabu pagi dan Sabtu malam berperan serta dalam proses latihan di Pendapa Ageng. Mangkunegara VII dan permaisuri adalah ahli dalam seni tari. Mangkunegara VII selalu melihat dan memimpin latihan, memberikan kritik yang membangun, memperbaiki gerak para penari, memberikan keterangan suatu karya tari, menciptakan suatu formasi dalam tari kelompok, serta memikirkan warna dan detail kostum (Holt, 1989:218).

Gusti Timur, karena putri Sultan dan permaisuri, maka di Mangkunegaran secara hieraki menempati strata sosial yang lebih tinggi dari pada garwa ampil Mangkunegara VII. Kedudukan strata sosial yang tinggi ditunjukkan dalam beberapa foto Mangkunegara VII dengan Gusti Timur. Pada umumnya, dalam pandangan Jawa seorang wanita berada di sisi kiri suaminya dalam upacara pernikahan maupun pertemuan-pertemuan resmi, tetapi dalam beberapa foto resmi yang ditemukan Gusti Timur berada di sisi kanan Mangkunegara VII. Artinya, sebagai putri Sultan Gusti Timur menempati strata sosial yang tinggi. Kedudukan Gusti Timur memberikan sebuah harapan untuk dapat menurunkan pewaris Mangkunegaran, sebagai trahing kusuma, rembesing madu, wijining tapa, tedhaking andana warih. Dalam mewujudkan hal tersebut Gusti Timur harus melahirkan putra laki-laki, sehingga dapat menggantikan kedudukan Mangkunegara VII. Harapan Gusti Timur tidak dapat terpenuhi, karena tidak dikaruniai putra lakilaki. Pernikahan Mangkunegara VII dan Gusti Timur dikaruniai seorang putri, bernama G.R.Aj. Siti Nurul Kamaril Ngasarati Kusumawardani. Gusti Nurul dilahirkan di Mangkunegaran pada Sabtu Legi 17 September 1921 (Hardjawahana, 1939:2; Soeryosoeyarso dan Darmawan, 1992:23).

Gusti Nurul merupakan putri tunggal, sehingga memiliki hubungan kedekatan yang sangat erat dengan Gusti Timur. Gusti Nurul melalui Gusti Timur banyak mendapatkan pendidikan mengenai sikap seorang putri bangsawan. Kedekatan itu menyebabkan Gusti Nurul dapat merasakan bahwa kedudukan ibunya sebagai permaisuri tidak sepenuhnya bahagia. Gusti Nurul merasakan, hal ini karena Mangkunegara VII memiliki banyak selir. Hal ini tercemin dalam pesan yang selalu disampaikan yaitu, "Nduk, mugo-mugo suk kowe ojo dimaru" (nak, mudah-mudahan nanti kamu jangan dimadu). Gusti Timur merasakan kebahagiaan ketika akan memiliki putra keduanya, namun karena keguguran menyebabkan kegembiraan 
tersebut tidak lama (Hermono, 2014:32-33). Menurut penulis, kesedihan Gusti Timur karena tidak memiliki anak laki-laki, yang dapat meneruskan tahta Mangkunegara. Gusti Timur yang diharapkan dapat menurunkan pewaris sebagai trahing kusuma, rembesing madu, wijining tapa, tedhaking andana warih, hanya dikaruniai seorang putri.

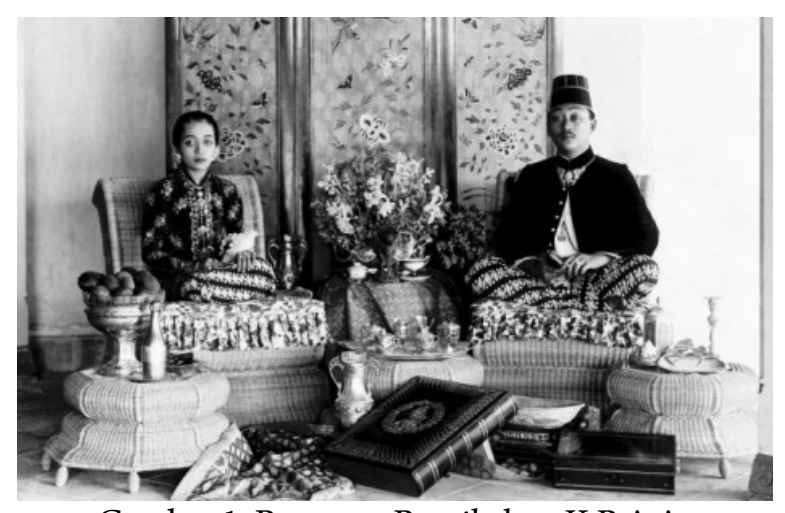

Gambar 1. Perayaan Pernikahan K.P.A.A.

Mangkunegara VII dan G.K.R. Timur di Pura

Mangkunegaran, Gusti Timur sebagai putri Sultan duduk di sebalah kanan suaminya.

Sumber: Koleksi Rekso Pustoko Mangkunegaran, Repro Sriyadi, 2019.

Sebagai cucu Sultan dan putri mahkota yang lahir dari permaisuri, Gusti Nurul secara hierarki menempati strata sosial lebih tinggi dari pada putra-putri Mangkunegara VII yang lahir dari garwa ampil. Gusti Nurul meskipun menempati strata sosial yang lebih tinggi, karena seorang putri maka tidak dapat mewarisi tahta di Mangkunegaran. Hal itu menyebabkan perlunya penegasan status Gusti Nurul untuk memperkuat kedudukannya sebagai putri mahkota. Dalam penegasan status Gusti Nurul tidak lepas dari peranan Gusti Timur sebagai permaisuri dan ibunya. Peranan permaisuri dalam sistem kerajaan Jawa memiliki pengaruh terhadap kedudukan anaknya. Misalnya, permaisuri Mangku Rat II yang bernama Gusti Kencana mengupayakan anaknya (R.M. Sutikna) dapat mewarisi tahta ayahnya. Ratu Ageng, permaisuri Susuhunan Paku Buwana I menobatkan seorang putranya, yaitu Pangeran Blitar untuk menggeser kedudukan Mangku Rat IV. Permaisuri Susuhunan Paku Buwana II mendesak agar secepatnya menandatangani teks perjanjian yang disodorkan Verenigde Oostindische Compagnie (VOC), supaya kedudukan putranya terjamin (Moedjanto,
1987:143-44). R.M. Suyitno diangkat menjadi Mangkunegara VI atas peranan ibunya yang merupakan permaisuri Mangkunegara IV bernama K.B.R.Ay. Mangkunegara IV (Wasino, 1994:73).

Gusti Nurul memiliki kedudukan putri mahkota, karena merupakan putri tunggal dari permaisuri. Sebagai putri mahkota, Mangkunegara VII selalu melibatkan dan memberi tugas resmi kepada Gusti Nurul yang harus dijalankan sebagai wakil dari Mangkunegaran. Salah satu tugas tersebut adalah menyajikan Tari Sari Tunggal di Belanda dalam acara pernikahan Pangeran Bernhard dan Putri Juliana pada 1937 (Hermono, 2014:27-74). Pujian dan sanjungan dari Belanda menunjukkan keberhasilan Gusti Nurul dalam menjalankan tugas sebagai putri mahkota (Hermono, 2014:71-78; Treur, 1987:7). Keberhasilan Gusti Nurul dalam menyajikan Tari Sari Tunggal di Belanda dimuat dalam beberapa majalah, salah satunya adalah "Een Javaansch Prinsesje Danst" dalam Op de Hoogte terbit Juni 1937 di Belanda. Keberhasilan Gusti Nurul tidak lepas dari peranan serta dukungan Gusti Timur (Soeryosoeyarso dan Darmawan, 1992:19).

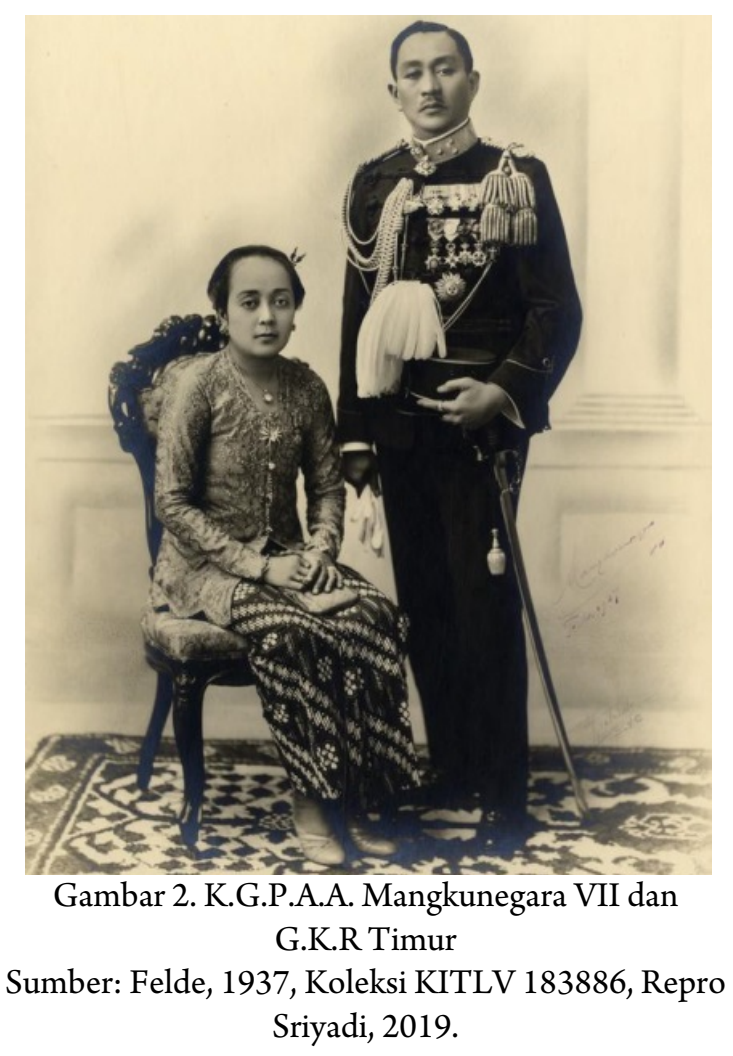

Salah satu cara untuk menegaskan status Gusti Nurul dibangun melalui eksistensinya dalam menari tari bedhaya dan srimpi. Keahliannya dalam 
membawakan tari bedhaya dan srimpi dapat meningkatkan kewibawaan sebagai putri keraton, sehingga memperkuat kedudukannya sebagai putri mahkota. Hal ini menjadi salah satu faktor penyerapan tari bedhaya dan srimpi gaya Yogyakarta di Mangkunegaran. Dalam menyerap tari gaya Yogyakarta tersebut tentunya tidak lepas dari peran serta Gusti Timur.

Tari dapat menjadi simbol status yang digunakan sebagai pelengkap kebesaran. Artinya, kewibawaan dari suatu kedudukan belum lengkap apabila belum memiliki suatu karya tari (Poerwanto, 1989:16). Tari bedhaya atau srimpi menjadi salah satu karya tari yang digunakan sebagai pelengkap kebesaran. Tari ini memiliki kandungan makna filosofis yang dalam terkait dengan nilai-nilai kehidupan berdasar pandangan dan gagasan masyarakat Jawa (Brongtodiningrat, 1981:17-21). Di Kasultanan Yogyakarta seorang putri diwajibkan belajar tari bedhaya dan srimpi sebagai sarana pendidikan karakter. Tari bedhaya dan srimpi mencerminkan kesusilaan dan keanggunan dari seorang putri keraton (Agatha dan Satronaryatmo, 1990:74-77; HughesFreeland, 2009:72-73; Suryobrongto, 1976:17).

\section{Absorpsi Tari Bedhaya Bedhah Madiun}

Pernikahan Mangkunegara VII dan Gusti Timur menyebabkan terjadinya interaksi budaya antara Mangkunegaran dan Kasultanan Yogyakarta. Interaksi budaya ditunjukkan dari pengiriman seniman Mangkunegaran untuk belajar di Kasultanan Yogyakarta, dan sebaliknya yaitu mengundang guru tari Kasultanan Yogyakarta ke Mangkunegaran. Pada awal masa pernikahan dengan Gusti Timur, Mangkunegara VII mengirimkan beberapa seniman untuk belajar tari golek di Kasultanan Yogyakarta. Salah satu penari yang dikirim adalah Jaikem atau $\mathrm{Ny}$. Ng. Mardusari, yang belajar tari Golek Clunthang di Yogyakarta. Mangkunegara VII juga memanggil guru tari dari Yogyakarta yang dapat mengajarkan Golek Lambangsari di Mangkunegaran. Putri tunggal Mangkunegara VII dan Gusti Timur, yaitu G.R.Aj. Siti Nurul Kamaril Ngasarati Kusumawardani disertai beberapa kerabat disekolahkan di KBW untuk belajar tari bedhaya dan srimpi (Soeryosoeyarso dan Darmawan, 1992:13-15; Suharti, 1990:72-76).
Interaksi budaya antara Mangkunegaran dan Kasultanan Yogyakarta juga ditunjukkan dari pergelaran tari gaya Yogyakarta di Mangkunegaran. Pada 6 September 1924 wayang orang gaya Yogyakarta dengan lakon Jaya Pusaka dipentaskan di Mangkunegaran. Pementasan tersebut merupakan hasil kerja sama antara KBW dan Jong Java atas arahan Mangkunegara VII. Pada 15 September 1941, wayang orang gaya Yogyakarta dengan lakon Sembadra Dados Ratu ing Nusa Tembinitelah dipergelarkan oleh Majelis Luhur Perguruan Nasional Taman Siswa di Mangkunegaran. Srimpi Merak Kesimpir gaya Yogyakarta juga dipergelarkan di Mangkunegaran dengan dua penari dari KBW dan dua penari dari Mangkunegaran (Soeryosoeyarso \& Darmawan, 1992 13-15; Suharti, 1990:74-76).

Menurut Abdullah (2007:83) dalam interaksi antaretnik simbol-simbol dapat saling dipertukarkan, yang menyebabkan terjadinya penyerapan ekspresi kebudayaan suatu etnis dalam lingkungan pemukiman tertentu. Pernikahan antara Mangkunegara VII dan Gusti Timur menyebabkan terjadinya interaksi budaya antara Mangkunegaran dan Kasultanan Yogyakarta. Interaksi budaya tersebut menyebabkan terjadinya penyerapan seni tari gaya Yogyakarta di Mangkunegaran.

Interaksi kebudayaan besar (lebih tinggi)

dan kebudayaan kecil (lebih rendah) mengakibatkan kebudayaan besar diserap oleh kebudayaan kecil. Krajan kecil berorientasi kepadanya krajan besar dan menjadikan seni yang lebih halus sebagai modelnya (Kayam, 1981:26). Pengaruh India masuk ke Jawa sebagai akibat dari dorongan para pemuka Jawa untuk mengambil bagian dalam kemajuan budaya. Pada masa itu kebudayaan India sedang menonjol kewibawaannya, sehingga terjadinya penyerapan kebudayaan Hindia oleh masyarakat Jawa (Sedyawati, 1985:10). Pernikahan antara putri dari sebuah kerajaan yang mempunyai gaya seni tersendiri (lebih tinggi) dengan seorang raja dari kerajaan lain, mengakibatkan adanya pengenalan seni dari negeri sang putri ke kerajaan suaminya (Soedarsono, 1979:87).

Pada masa pemerintahan Mangkunegara VI kesenian mengalami kemunduran, sehingga Mangkunegara VII merintis kembali dalam 
mengembangkan kesenian. Hal ini menjadi salah satu faktor terjadinya penyerapan tari gaya Yogyakarta di Mangkunegaran, karena di Yogyakarta telah didirikan sekolah seni KBW. B.P.H. Suryadiningrat dan G.P.H. Tejokusumo mendirikan KBW pada 17 Agustus 1918, didukung oleh 14 ahli dalam bidang karawitan dan tari, yang keseluruhan memiliki hubungan erat dengan Kasultanan Yogyakarta. KBW mendapat izin resmi dari Hamengku Buwana VII yang diteruskan pada masa Hamengku Buwana VIII. Tujuan pendirian KBW adalah mengupayakan tari klasik gaya Yogyakarta (termasuk bedhaya dan srimpi) untuk dapat dipelajari di luar tembok keraton (Soerjadiningrat, 1993:1-3). KBW merupakan pemasok utama penari-penari andal dalam pertunjukan-pertunjukan besar di Keraton Kasultanan Yogyakarta pada era pemerintahan Hamengku Buwana VIII (Pramutomo, 2010:79). KBW memiliki penggarapan tari secara sunguhsungguh dan memelopori pendidikan tari dengan metode pengajaran yang teratur dan memuaskan (Rustopo, 1990:148). Prestasi KBW tersebut menyebabkan Mangkunegaran yang sedang merintis pengembangan kesenian menyerap tari gaya Yogyakarta melalui KBW.

Pada 1934 Gusti Nurul disekolahkan di KBW Yogyakarta. Setiap Minggu, Gusti Nurul disertai beberapa kerabat dan para niyaga Mangkunegaran berlatih di Yogyakarta. Rombongan berangkat pada pagi hari dan pulang sore hari dengan menaiki kereta api. Pelatih tari di KBW adalah Gusti Tejokusumo, kakak Gusti Timur. Kegiatan ini berjalan atas perkenaan Mangkunegara VII, yang sebenarnya tertarik pada dinamika karawitan Yogyakarta. Materi pembelajaran yang pertama adalah tari Sari Tunggal, sebagai dasar tari putri gaya Yogyakarta. Selanjutnya Gusti Nurul belajar tari Srimpi Pandhelori, Bedhaya Bedhah Madiun, dan Srimpi Muncar (Soemarsono, Brotohatmodjo, dan Widyohamijoyo, 2011:33; Soeryosoeyarso dan Darmawan, 1992:15-16).

Tari Bedhaya Bedhah Madiun di Mangkunegaran pertama kali dipergelarkan pada 16 Juni 1939 (Gambar 3), dalam rangka memperingati Tri Windu Jumeneng Mangkunegara VII (Anonim 1939; Suharti 1990:80). Tari Bedhaya Bedhah Madiun ditarikan oleh tujuh orang penari, yaitu Gusti Nurul, R.Aj.
Bandinah, R.Aj. Surarsi, R.Aj. Pudiatmi, R.Aj. Sunarni, R.Aj. Sunituti (Gusti Putri Mangkunegara VIII), dan Nduk Nah (seorang abdi dalem Mangkunegaran yang pandai menari). Dalam pergelaran tersebut Gusti Nurul berperan sebagai batak, sedangkan R.Aj. Bandinah sebagai endhel (Soemarsono, dkk., 2011:35).

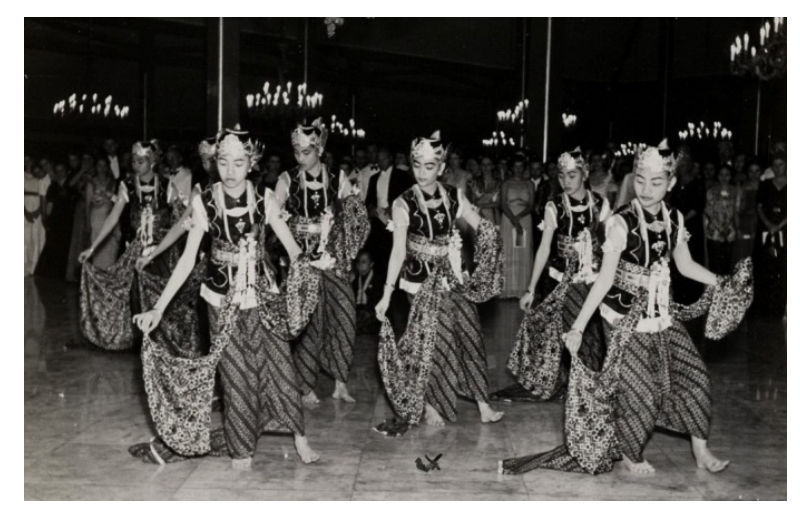

Gambar 3. Pergelaran Tari Bedhaya Bedhah Madiun di Mangkunegaran pada 16 Juni 1939

dalam rangka memperingati Tri Windu Jumeneng Mangkunegara VII.

Sumber: Koleksi Rekso Pustaka Mangkunegaran, Reproduksi Sriyadi 2019.

\section{Simpulan}

Tari yang berkembang di Mangkunegaran pada dasarnya menggunakan gaya Surakarta. Pada masa pemerintahan Mangkunegara VII terdapat tari Bedhaya Bedhah Madiun dengan gaya Yogyakarta. Berdasar analisis yang dilakukan, Mangkunegaran memiliki tari Bedhaya Bedhah Bedhah Madiun disebabkan oleh beberapa faktor. Keadaan sosial politik Mangkunegaran yang kurang stabil menyebabkan terjadinya politik pernikahan antara Mangkunegaran dengan Kasultanan Yogyakarta. Dampak dari politik pernikahan adalah terjadinya interaksi budaya antara Mangkunegaran dan Kasultanan Yogyakarta. Interaksi budaya itu didukung dengan adanya kebijakan Mangkunegara VII untuk mengembangkan kesenian di Mangkunegaran. Gaya kepemimpinan Mangkunegara VII yang demokratis, modern, dan berpandangan luas menyebabkan terjadinya absorpsi tari gaya Yogyakarta dari interaksi budaya tersebut. Dalam menyerap tari gaya Yogyakarta dimanfaatkan Gusti Timur untuk menegaskan kedudukan putri tunggalnya yaitu Gusti Nurul, sehingga memengaruhi perkembangan seni tari di 
Mangkunegaran. Tari Bedhaya Bedhah Madiun merupakan salah satu karya tari yang berhasil diserap oleh Gusti Nurul melalui sistem pembelajaran di KBW.

\section{Referensi}

Abdullah, I. (2007). Konstruksi dan Reproduksi Kebudayaan. Yogyakarta: Pustaka Pelajar.

Agatha, dan M. Satronaryatmo (1990). "Joged Kanggo Sarana Ngalusake Bebuden.” Jaya Baya, 74-77.

Anonim (1939). "Bedaja-Dans van Zeven Jonkvrouwen, Uitgevoerd bij Gelegenheid van het Triwindhoe-Bestuursjubeleum van Z.H. Pangeran Adipati Aria Mangkoenagara VII." Surakarta: t.p. Koleksi Rekso Pustoko Pura Mangkunegaran, MN. 345.

Anonim (1986). "Pahargyan Mangkunegaran Tigang Windu." Majalah Djawa, No. 48 Tahun ke XIV, 16 Juni 1939. Terj. Soeroyo Tarusuwardjo. Koleksi Rekso Pustoko Pura Mangkunegaran, MN 783.

Anonim (1987a). "Menyambut Yubileum Pemerintah (25 Tahun) Pangeran Mangkunagara VII." Tijdbeeld, Maret 1941. Terj. Husodo Pringgokusumo. Surakarta: t.p. Koleksi Rekso Pustoko Pura Mangkunegaran, MN. 983.

Anonim (1987b). "Pangeran Adipati Ario Mangkunagoro VII dan Gusti Timur dari Yogyakarta: Suatu Perkawinan Raja Jawa," terj. Husodo Pringgokusumo. Surakarta: t.p. Koleksi Rekso Pustoko Pura Mangkunegaran, MN. 977.

Anonim (1989). "Karier (Riwayat Pekerjaan) Pangeran Adipati Aria Mangkunegara VII, yang telah disampaikan kepada Volksraad pada Tahun 1921," terj. Husodo Pringgokusumo. Surakarta: Rekso Pustoko Pura Mangkunegaran, MN. 1410.

Anonim (1996). "P.A.A. Mangkunegara VI." Dalam, Majalah Djawa Edisi XV. Terj. H.R. Soetono. Koleksi Rekso Pustoko Pura Mangkunegaran, MN. 2005.
Anonim (t.t.) "Lelampahan Suwargi Kanjeng Gusti Pangeran Adipati Ariya Mangkunagara VII ing Surakarta," Surakarta: t.p. Koleksi Rekso Pustoko Pura Mangkunegaran, MN. 486.

Brandon, J. R. (1989). Seni Pertunjukan di Asia Tenggara, terj. R.M. Soedarsono. Yogyakarta: ISI Yogyakarta.

Brongtodiningrat, K. P. H. (1981). "Falsafah Beksa Bedhaya Sarta Beksa Srimpi ing Ngayogyakarta." Kawruh Joged Mataram. Yogyakarta: Yayasan Siswa Among Beksa.

Cannegieter, H. G. (1986). "Pangeran Adipati Ario Mangkunagara VII.” Morks-Magazijn, Maret 1937, terj. Husodo Pringgokusumo. Koleksi Rekso Pustoko Pura Mangkunegaran, MN. 846.

Darmawan, R. A. H. (2006). Mengenang B.R.M. Soerya Soeparto, Bergerak dan Melangkah Maju untuk Bangsanya. Surakarta: t.p. Koleksi Rekso Pustoko Pura Mangkunegaran, MN. 1000.

Djlantik, I. A. A. B. (1989). "Surat Pujian.” Dalam Buku Kenangan Tri Windu Mangkunegara VII, terj. Husodo Pringgokusumo. Surakarta: t.p. Koleksi Rekso Pustoko Pura Mangkunegaran, MN. 1518.

Endter, I. L. (2000). "Community Memory Building Multimedia Archives on the Internet." Tesis Program in Media Arts and Sciences, School of Architecture and Planning at the Massachusetts Institute of Technology.

van Eysselsteijn, B. (1937). "Een Javaansch Prinsesje Danst." Op de Hoogte, Juni, 18283.

Hardjawahana, S. (1939). "Sampean Dalem Kangdjeng Goesti Pangeran Adipati Arja Mangkoenagara ingkang kaping VII." Wahjoe, Juni, 1-3.

Hermono, U. (2014). Gusti Noeroel: Streven Naar Geluk (Mengejar Kebahagiaan). Jakarta: Kompas.

Holt, C. (1989). "Perkembangan Seni Tari di Mangkunegaran.” Buku Kenangan Tri Windu Mangkunegara VII, terj. Husodo Pringgokusumo. Surakarta: t.p. Koleksi: 
Rekso Pustoko Pura Mangkunegaran, MN. 1518.

Holt, C. (2000). Melacak Jejak Perkembangan Seni di Indonesia, terj. R.M. Soedarsono. Bandung: Masyarakat Seni Pertunjukan Indonesia.

Houben, V. J. H. (1989). "Kedudukan Pangeran Mangkunegara dalam Struktur Politik yang Terpecah Belah di Jawa Tengah,” terj. Husodo Pringgokusumo. Surakarta: Rekso Pustoko Pura Mangkunegaran, MN 1424.

Hughes-Freeland, F. (2009). Komunitas yang Mewujud: Tradisi Tari dan Perubahan di Jawa. Yogyakarta: Gadjah Mada University Perss.

Kartodirdjo, S. A. S., dan Hatmosuprobo, S. (1987). Perkembangan Peradaban Priyayi. Yogyakarta: Gadjah Mada University Perss.

Koentjaraningrat (1984). Kebudayaan Jawa. Jakarta: Balai Pustaka.

Koentjaraninngrat (2015). Pengantar IImu Antropologi. Edisi Revisi. Jakarta: Rineka Cipta.

Kusmayati, A. M. H. (1988). "Bedhaya di Pura Paku Alaman: Pembentukan dan Perkembangannya 1909-1987.” Tesis, Program Studi Sejarah Pascasarjana Universitas Gadjah Mada.

Kusumo, D. N. A. (2015). “Analisis Koreografi Bedhaya Bedhah Madiyun Gaya Yogyakarta: Rekonstruksi Juni 2014 oleh R.Ay. Sri Kadaryati." Skripsi Program Studi S-1 Tari Jurusan Tari Fakultas Seni Pertunjukan Institut Seni Indonesia Yogyakarta.

Larson, G D. (1990). Masa Menjelang Revolusi: Keraton dan Kehidupan Politik di Surakarta, 1912-1942, terj. A. B. Lapian. Yogyakarta: Gadjah Mada University Perss.

van Lelyveld, Th. B. (1989). "Sebuah Kenangan." Buku Kenangan Tri Windu Mangkunegara VII, terj. Husodo Pringgokusumo. Surakarta: t.p. Koleksi Rekso Pustoko Pura Mangkunegaran, MN. 1518.

Metz, Th. M. (1987). "Mangkunegaran: Analisis Sebuah Kerajaan Jawa," terj. Husodo
Pringgokusumo. Koleksi Rekso Pustoko Pura Mangkunegaran, MN. 832.

Moedjanto, G. (1987). Konsep Kekuasaan Jawa: Penerapannya oleh Raja-raja Mataram. Yogyakarta: Kanisius.

Muhlenfeld, A. (1989). "Beberapa Kenangan Pribadi.” Buku Kenangan Tri Windu Mangkunegara VII, terj. Husodo Pringgokusumo. Surakarta: t.p. Koleksi Rekso Pustoko Pura Mangkunegaran, MN. 1518.

Munarsih, S. (2010). "Tari Bedhaya Bedhah Madiun Pura Mangkunegaran Surakarta, Legitimasi Kekuasaan Mangkunegara VII Melalui Kebudayaan.” Tesis Program Studi Kajian Budaya UNS.

Pakempalan Pengarang Serat ing Mangkunagaran, dan Kamajaya (1993). Babad KGPAA Mangkunegara I (Pangeran Sambernyawa). Jakarta: Yayasan Mangadeg dan Yayasan Centhini.

Poerwanto (1989). "Nlusur Tari Lewat Candhi: Tari Jawa Kuna Dadi Simbol Status.” Mekar Sari, September 20, 15-16.

Pramutomo, R. M. (2010). Tari, Seremoni, dan Politik Kolonial II. Surakarta: ISI Press.

Pramutomo, R. M., Aswoyo Joko, dan Aton Rustandi Mulyana. (2016). Revitalisasi Budaya Lokal Berbasis Ekspresi Seni Komunitas. Surakarta: ISI Press.

Redfield, R. (1982). Masyarakat Petani dan Kebudayaan, terj. Daniel Dhakidae. Jakarta: Rajawali.

Rohmawati, D. (2016). “Kajian Nilai Estetis Tari Bedhaya Bedhah Madiun di Pura Mangkunegaran Surakarta." Skripsi Jurusan Pendidikan Seni Drama, Tari, dan Musik Fakultas Bahasa dan Seni Universitas Negeri Semarang.

Rustopo (1990). “Gendon Humardani (19231983) Arsitek dan Pelaksana Pembangunan Kehidupan Seni Tradisi Jawa yang Modern MenIndonesia suatu Biografi." Tesis Program Studi Sejarah Pascasarjana Universitas Gadjah Mada. 
Sajid, R. M. (1985). "Carios Wontenipun Beksan Bedhaya Bedhah Madiun.” Koleksi Rekso Pustoko Pura Mangkunegaran, G. 165.

Sedyawati, E. (1985). "Pengaruh India pada Kesenian Jawa: Suatu Tinjauan Proses Akulturasi." Soedarsono, R. M. Pengaruh India, Islam, dan Barat dalam Proses Pembentukan Kebudayaan Jawa. Yogyakarta: Proyek Penelitian dan Pengkajian Kebudayaan Nusantara Direktorat Jendral Kebudayaan Departemen P dan K.

Singgih, R. P. (1986). Partini: Tulisan Kehidupan Seorang Putri Mangkunegaran. Jakarta: Djambatan.

Soedarsono, R. M. (1979). "Hubungan dan Pengaruh Tari Jawa Terhadap Tari Bali." Laporan Penelitian Proyek Pengembangan Institut Kesenian Indonesia Jakarta.

Soedarsono, R.M. (2003). Seni Pertunjukan Dari Perspektif Politik, Sosial, dan Ekonomi. Yogyakarta: Gadjah Mada University Perss.

Soemarsono, R., Wishnu, R. P., Widyohamijoyo, P.S. (2011). Lembar Kenangan Gusti Noeroel. Jakarta: HKMN.

Soemaryatmi (1998). "Kehidupan Tari Gaya Surakarta di Daerah Istimewa Yogyakarta." Tesis Program Studi Pengkajian Seni Pertunjukan Pascasarjana Universitas Gadjah Mada.

Soeratman, D. (1989). Kehidupan Dunia Kraton Surakarta 1830-1939. Yogyakarta: Taman Siswa.

Soerjadiningrat, R. M. (1993). "Krida Beksa Wirama." Majalah Djawa, Edisi Tahun. 1940, terj. Husodo Pringgokusumo. Koleksi Rekso Pustoko, Pura Mangkunega-ran, G.480.

Soeryosoeyarso, G. R. dan H. Darmawan (1992). "Adaptasi Tari Gaya Yogyakarta terhadap Tari Gaya Mangkunegaran pada Waktu Mangkunegara VII.” Kebudayaan Kraton sebagai Puncak Kebudayaan Daerah Pelestarian Warisan Adiluhung Leluhur Bangsa Menyongsong Era Tinggal Landas. Yogyakarta: Kagama UGM.
Stutterheim, W. F. (1989). "Sri Paduka Mangkunegara dan Masa Silam Pulau Jawa." Buku Kenangan Tri Windu Mangkunegara VII, terj. Husodo Pringgokusumo. Surakarta: t.p. Koleksi Rekso Pustoko Pura Mangkunegaran, MN. 1518.

Suharti, T. (1990). “Tari di Mangkunegaran Suatu Pengaruh Bentuk dan Gaya dalam Dimensi Kultural 1916-1988.” Tesis Program Studi Sejarah Pascasarjana Universitas Gadjah Mada.

Suharti, T. (2015). Bedhaya Semang Karaton Ngayogyakarta Hadiningrat Reaktualisasi Sebuah Tari Pusaka. Yogyakarta: Kanisius.

Sunarmi (2005). Interior Pracimayasa di Pura Mangkunegaran Surakarta: Karya Budaya Mangkunegara VII (Kajian Estetik). Surakarta: UNS Press.

Suryobrongto, G. B. P. H. (1976). Tari Klasik Gaya Yogyakarta. Yogyakarta: Museum Kraton Yogyakarta.

Treur, M. J. J. (1987). “Pidato Gubernur Surakarta Ditujukan Kepada Sri Paduka Pangeran Adipati Ario Mangkunagara VII pada Pesta Peringatan Panobatan Beliau Serta Hari Ulang Tahun Beliau ke-50 pada tanggal 19 Mei 1934 atau 4 Sapar Tahun Wawu 1865," terj. Husodo Pringgokusumo. Koleksi Rekso Pustoko Pura Mangkunegaran, MN. 1040.

Kayam, U. (1981). Seni Tradisi Masyarakat. Jakarta: Sinar Harapan.

Ventresca, M. J., dan J. W. Mohr. (2002). Archival Research Methods. USA: Blackwell Publishers.

Wasino (1994). “Kebijaksanaan Pembaharuan Pemerintahan Praja Mangkunegaran: Studi tentang Strategi Pemerintahan Tradisional dalam Menanggapi Perubahan Sosial (Akhir Abad XIX-Pertengahan Abad XX).” Tesis Program Studi Sejarah Pascasarjana Universitas Gadjah Mada.

Wedyodiningrat (1944). "SP Mangkunagoro VII kalijan Kaboedajan Djawi.” Koleksi Rekso Pustoko Pura Mangkunegaran MN 414. 